\title{
APPARENT EFFICIENCY OF IMMUNOGLOBULIN ABSORPTION IN NEWBORN CALVES ORALLY TREATED WITH ZEOLITE
}

\author{
GVOZDIĆ D*, STOJIĆ V*, ŠAMANC H*, FRATRIĆ NATALIJA* and DAKOVIĆ ALEKSANDRA**
}

*Faculty of Veterinary Medicine, University of Belgrade, Serbia

**Institute For Technology of Nuclear and Other Raw Materials, Belgrade, Serbia

(Received 12. February 2008)

Sixty Holstein newborn calves, which were immediately after parturition separated from their dams and placed in individual pens, were randomly assigned to 4 treatment groups (15 calves per group). All calves were bottle-fed twice a day during the first 48 hours after partus, with their mothers' colostrum in 12 hour intervals, starting two hours after partus, according to the following model: i) group 1 (G1) received $0.75 \mathrm{~L}$ of colostrum (C) per meal, with $20 \mathrm{~mL}$ of $25 \%$ zeolite (clinoptilolite) suspension in distilled water; ii) group 2 (G2) received $1.5 \mathrm{~L}$ of $\mathrm{C}$ per meal, with $20 \mathrm{~mL}$ of $25 \%$ zeolite suspension in distilled water; iii) group 3 (G3) received $0.75 \mathrm{~L}$ of $C$ per meal, and iv) group 4 (G4) received $1.5 \mathrm{~L}$ of $C$ per meal. Blood serum immunoglobulin $G$ (IgG) concentrations at $0 \mathrm{~h}$ (before $C$ ingestion) $6 \mathrm{~h}, 24 \mathrm{~h}$ and $48 \mathrm{~h}$ after partus and colostrum IgG concentrations were determined using commercial sRID plates (INEP, Zemun, Serbia). Apparent efficiency of absorption (AEA\%) was calculated for individual calves at $6 \mathrm{~h}$ after partus. Calf blood serum IgG concentrations at all investigated time intervals in $\mathrm{G} 1$ were increased compared to G3, with a significant increase at $6 h$ after partus $(15 \pm 4: 10 \pm 5 \mathrm{~g} / \mathrm{L}, p<0.05)$. The same relationship was evident between $\mathrm{G} 2$ and $\mathrm{G} 4$, with significant mean IgG blood serum differences evident at 6,24 . and 48. hour after partus. Calf blood serum IgG concentration was significantly higher in G2 compared to all experimental groups at 6, 24 and $48 \mathrm{~h}$ after partus. Apparent efficiency of absorption (AEA\%) at 6h after partus was significantly higher in G1, compared to all other experimental groups.

Key words: Immunoglobulin G, zeolite, calves, apparent efficiency of absorption.

\section{INTRODUCTION}

Immune protection after parturition in newborn mammals is one of the major survival problems. Colostrum is the only source of immunoglobulin (lg) for newborn farm animals, since the placenta does not allow transport of Ig from

maternal to foetal circulation (Quigley et al., 1998). Colostral Ig concentration is 
very high (up to $100 \mathrm{~g} / \mathrm{L}$ ), and Ig molecules are readily resorbed from the intestine of newborn animals (Stott et al., 1979a, 1979b, 1979c, 1983; Cabello et al., 1980; Kruse, 1983). In unsuckled newborn calves blood immunoglobulin G (IgG) concentration is extremely low $(<0.1 \mathrm{~g} / \mathrm{L})$ (Arthington et al., 2000). However, measurable blood serum IgG concentrations in newborn calves can be detected before colostrum intake (Vukotić et al., 1976; Vukotić et al., 1979; Edvards et al, 1982). Not just calf morbidity and mortality (Besser et al., 1994), but also their long-term performance is directly related to low blood Ig concentrations (Wittum et al., 1995). Failure of passive immunity transfer (FPT) may be attributed to an inadequate amount of IgG in the colostrum, insufficient quantity of ingested colostrum and inefficient IgG absorption (Lee et al., 1983; Abel Francisco et al., 1993; Rea et al, 1996; Quigley et al, 1998). Recent investigations in Canada concerning risk factors associated with FPT revealed that $19 \%$ of 225 newborn calves from 45 herds had serum IgG concentrations less than $10 \mathrm{~g} / \mathrm{L}$ (Filteau et al, 2003). Jaster (2005) reported that over $40 \%$ of dairy heifer calves sampled by the National Dairy Heifer Evaluation Project in the USA had serum IgG concentrations below $10 \mathrm{~g} / \mathrm{L}$, and more than $25 \%$ of calves had levels below $6.2 \mathrm{~g} / \mathrm{L}$.

Numerous attempts have been made to artificially augment the ability of calves to attain passive immune protection, such as feeding stored surplus colostrum (Foley et al., 1978), injecting lg solutions (Quigley et al., 1996), feeding dried colostrum (Morin et al., 1997; Garry et al., 1996), concentrated milk whey (Mee et al., 1996), and supplementing dried bovine serum protein (Arthington et al., 2000). Furthermore, addition of trypsin inhibitor to maternal colostrum increased serum concentrations of IgG by $16 \%$, and IgM by $30 \%$, in Jersey calves, regardless of their age at the time of first feeding (0. or 12. hours after birth) (Quigley et al., 1995). Bovine antiserum injection at birth also can induce an increase in the apparent efficacy of absorption of colostral lg by $42 \%$ in calves at 24. hours after treatment (Pedersen et al., 2000). However the antiserum injection could possibly somehow trigger the active synthesis of IgG.

Most of these attempts are based on the same approach, namely to provide some other source of Ig instead and/or additional to colostrum. Our previous studies have indicated that peroral treatment with zeolite (clinoptilolite) based mineral adsorbent could induce an increase in newborn calf blood serum IgG concentration (Stojić et al., 1995; Stojić et al., 1998; Fratrić et al., 2005). This novel approach has been utilized in this experiment as our objective was to determine the apparent efficiency of absorption (AEA\%) in newborn calves treated with zeolite (clinoptilolite) receiving different amounts of colostrum.

\section{MATERIALS AND METHODS}

Zeolite. A sample of natural zeolitic rich tuff from the Zlatokop deposit (Vranje, southern Serbia) was used in this study. The mineralogical composition of the natural zeolitic tuff was primarily clinoptilolite/heulandite (HEU) - minimum $85 \%$, with trace amounts of feldspar and quartz, as determined by X-ray powder diffraction (XRPD) analysis. HEU group zeolites have the same framework topology, but clinoptilolite and heulandite are differentiated by their chemical 
Acta Veterinaria (Beograd), Vol. 58. No. 4, 345-355, 2008.

Gvozdić D et al.: Apparent efficiency of immunoglobulin

absorption in newborn calves orally treated with zeolite

composition, thermal stability, and ${ }^{1} \mathrm{H}$ NMR spectra (Mumpton, 1998; Ward and McKague, 1994). Thermal stability study (Mihajlović-Radosavljević et al., 2003) and ${ }^{1} \mathrm{H}$ NMR analysis (Daković et al., 2007), showed that natural zeolitic tuff from Zlatokop deposit (Serbia) is rich in mineral clinoptilolite.

Chemical composition of the clinoptilolite rich zeolitic tuff (clinoptilolite), determined by atomic absorption spectroscopy, is given in Table 1 .

Table 1. Chemical composition of the mineral adsorbent (\%)

\begin{tabular}{|l|c|c|c|c|c|c|c|c|c|}
\hline Component & $\mathrm{SiO}_{2}$ & $\mathrm{Al}_{2} \mathrm{O}_{3}$ & $\mathrm{Fe}_{2} \mathrm{O}_{3}$ & $\mathrm{TiO}_{2}$ & $\mathrm{CaO}$ & $\mathrm{MgO}$ & $\mathrm{Na}_{2} \mathrm{O}$ & $\mathrm{K}_{2} \mathrm{O}$ & L.I. \\
\hline Content, \% & 64.21 & 11.48 & 0.88 & 0.25 & 4.55 & 1.45 & 1.71 & 1.29 & 14.00 \\
\hline
\end{tabular}

The predominant cation associated with clinoptilolite was calcium and the minimum cation exchange capacity (CEC) was $146 \mathrm{mmolM}^{+} / 100 \mathrm{~g}$ (Table 2) measured by the ammonium chloride method.

Table 2. CEC and exchanging cations of the mineral adsorbent

\begin{tabular}{|l|c|c|c|c|c|}
\hline Exchangeable cation & $\mathrm{Ca}^{++}$ & $\mathrm{Mg}^{++}$ & $\mathrm{Na}^{++}$ & $\mathrm{K}^{+}$ & $\Sigma$ \\
\hline $\mathrm{CEC}, \mathrm{mmolM}+/ 100 \mathrm{~g}$ & 95 & 13 & 22 & 16 & 146 \\
\hline
\end{tabular}

Thermogravimetric analysis of the used clinoptilolite (plot is not shown) showed continuous weight loss during heating up to $800^{\circ} \mathrm{C}$, due to the loss of hygroscopic water and the loss of water residing in the channels and cavities of the zeolite framework; the total water content was $13.80 \%$. Thermal analysis was performed on a Netzsch STA 409 EP. Sample was heated $\left(20-800^{\circ} \mathrm{C}\right)$ in air atmosphere, with a heating rate of $10^{\circ} \mathrm{C} / \mathrm{min}$.

A fine powder, $<10 \mu \mathrm{m}$ fraction of clinoptilolite, was used in the experiments. The particle size of the material was determined on a Coulter Counter. The average particle size was $4.5 \mu \mathrm{m}(99.9 \%$ of the particles $<10 \mathrm{~mm}$ and $90.0 \%$ $<7 \mu \mathrm{m})$. For experiments, $25 \%$ suspension of clinoptilolite in distilled water was prepared.

Animals and treatments. The experiment was carried out on a total number of 60 newborn Holstein calves, both sexes, weighting $35 \pm 3 \mathrm{~kg}$ (mean $\pm \mathrm{SD}$ ), which were immediately after parturition separated from their dams and placed in individual pens. Calves were divided in four experimental groups, with 15 calves each. All calves were bottle-feed twice/day during the first 48 hours after partus, with their mother's colostrum in 12 hour intervals, starting two hours after partus. Calves from experimental group 1 (G1) and 2 (G2) received $0.75 \mathrm{~L}$ and $1.5 \mathrm{~L}$ of colostrum per meal, respectively, with $20 \mathrm{~mL}$ of $25 \%$ zeolite (clinoptilolite) suspension in distilled water. Calves from group $3(G 3)$ and 4 (G4) received 0.75L and $1.5 \mathrm{~L}$ of colostrum, respectively, without zeolite suspension. 
Blood serum samples. Blood samples were taken from the jugular vein of calves at 6, 24 and 48 hours after birth. After spontaneous coagulation at room temperature blood serum was separated and stored at $-20^{\circ} \mathrm{C}$ until analyzed.

Colostral serum preparation. Colostral sera were obtained from first colostrum after fat and casein removal. Fat removal was performed by centrifugation of colostral samples at 2000 RPM for one hour, when fat was separated in the upper layer and manually removed from the samples. Casein was precipitated by homogenization of $2 \mathrm{~mL}$ of $2 \%$ acetic acid, added in $1 \mathrm{~mL}$ of fat-free casein sample, following centrifugation at 3000 RPM for $10 \mathrm{~min}$. and colostral serum was removed by Pasteur pipette. Colostral serum samples were stored at $-20^{\circ} \mathrm{C}$ until analyzed.

Immunoglobulin $G$ analysis. Blood serum IgG and first colostrum IgG concentrations were determined using single radial immunodiffusion (sRID) plates containing monospecific antisera in buffered agarose. Reference standards were pipetted $(5 \mu \mathrm{L})$ into the first four wells of each agarose plate, and serum and colostral whey samples were pipetted $(5 \mu \mathrm{L})$ into the remaining wells of each agarose plate. The IgG serum samples were diluted 1:30 with saline $(2.9 \mathrm{~mL}$ saline and $0.1 \mathrm{~mL}$ sera) before they were added to SRID plates. Colostral whey for IgG (1:60) was diluted with saline (5.9 mL saline and $0.1 \mathrm{~mL}$ colostral whey) before placement in SRID plates. The plates were left undisturbed at room temperature for 24 to $48 \mathrm{~h}$, and the ring diameters were read using a finescale comparator RIDmeter (millimeters). The diameters were plotted on a scale with reference standards to obtain the concentrations serum and colostral $\mathrm{lgG}(\mathrm{g} / \mathrm{L})$. Each sample was set in duplicate. Duplicate analyses of samples gave a repeatability within $5 \%$.

Apparent efficiency of absorption (AEA\%). Apparent efficiency of absorption (AEA\%) was calculated for individual calves at $6 \mathrm{~h}$ after partus, by the method of Husband et al., (1973): AEA $=[($ Peak serum lg concentration $) \times(0.07 \mathrm{BW})$ $(100 \%)] /$ [(Colostrum Ig concentration) (L colostrum fed)]. Values of AEA\% were calculated using an average weight of $35 \mathrm{~kg}$ for each calf.

Statistical analysis. The results are expressed as mean values and standard deviation (SD), for each group of animals. The results were subjected to analysis of variance (ANOVA), and statistical significance of differences between mean values was calculated using LSD test, at $95 \%$ and $99 \%$ probability.

\section{RESULTS AND DISCUSSION}

The mean IgG concentrations in the first colostrum of all experimental groups varied between $82 \pm 16$ to $100 \pm 18 \mathrm{~g} / \mathrm{L}$ (G1 and G4, respectively), and are presented in Figure 1. There were no significant differences between first colostrum IgG concentrations fed to all groups of calves. 
Acta Veterinaria (Beograd), Vol. 58. No. 4, 345-355, 2008.

Gvozdić D et al.: Apparent efficiency of immunoglobulin

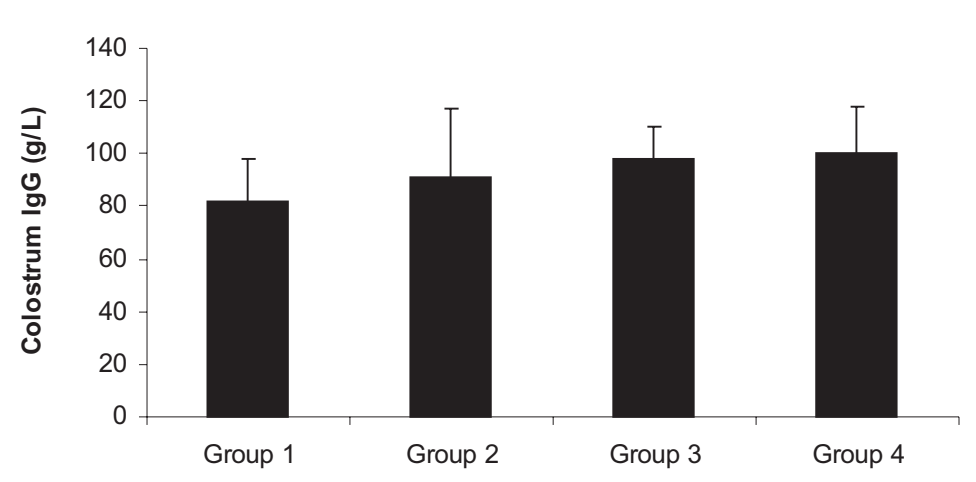

Figure 1. Mean IgG concentrations (Mean $\pm S D \mathrm{~g} / \mathrm{L}$ ) in the first colostrum

Blood serum IgG concentrations in all four experimental groups of calves at different time intervals and the statistical significance of differences between means in the same time interval are presented in the Table 3.

Table 3. Calf blood serum IgG concentrations ( $\bar{X} \pm S D ; g / L)$ at different time intervals after partus

\begin{tabular}{|c|c|c|c|c|}
\hline $\begin{array}{c}\text { Experimental } \\
\text { group }^{1}\end{array}$ & 0. hour* & 6. hour & 24. hour & 48. hour \\
\hline \hline G1 & $1 \pm 1$ & $15 \pm 4^{\mathrm{b}}$ & $22 \pm 10^{\mathrm{bc}}$ & $21 \pm 9^{\mathrm{bc}}$ \\
\hline $\mathrm{G} 2$ & $1 \pm 1$ & $21 \pm 8^{\mathrm{a}}$ & $35 \pm 9^{\mathrm{a}}$ & $30 \pm 10^{\mathrm{a}}$ \\
\hline $\mathrm{G} 3$ & $1 \pm 1$ & $10 \pm 5^{\mathrm{c}}$ & $18 \pm 5^{\mathrm{c}}$ & $16 \pm 5^{\mathrm{b}}$ \\
\hline $\mathrm{G} 4$ & $1 \pm 1$ & $15 \pm 7^{\mathrm{b}}$ & $25 \pm 12^{\mathrm{b}}$ & $23 \pm 9^{\mathrm{c}}$ \\
\hline
\end{tabular}

${ }^{a b c}$ Means in the same column without common superscript are significantly different $(p<0.05)$; *hours postpartum;

${ }^{1}$ Calves in $\mathrm{G} 1$ and $\mathrm{G} 2$ received oral clinoptilolite suspension; calves in $\mathrm{G} 1$ and $\mathrm{G} 3$ received $0.75 \mathrm{~L}$ of colostrum; calves in G2 and G4 received $1.5 \mathrm{~L}$ of colostrum.

Detectable blood serum IgG concentrations in newborn calves were evident before colostral intake, and similar results have been reported by many other researchers (Vukotić et al., 1976; Vukotić et al., 1979; Edvards et al., 1982). Since blood serum IgG concentrations before colostral intake had great individual variations there were no significant differences between the four experimental groups.

Calf blood serum IgG concentrations at all investigated time intervals in G1, receiving zeolite treatment with colostrum were higher compared to $G 3$, receiving only colostrum. The differences in mean blood serum IgG concentrations between G1 and G3 were statistically significant at 6 . hour postpartum 
$(15 \pm 4: 10 \pm 5 \mathrm{~g} / \mathrm{L}, \mathrm{p}<0.05)$. The same relationship is evident between $\mathrm{G} 2$ and $\mathrm{G} 4$, while the differences in mean blood serum IgG concentrations were statistically significant at all time intervals except at the begining of the experiment (0. hour). An increase in the amount of colostral intake from $0.75 \mathrm{~L}$ to $1.5 \mathrm{~L}$ induced a significant increase in calf blood serum IgG concentration at $6 \mathrm{~h}, 24 \mathrm{~h}$ and $48 \mathrm{~h}$, irrespective to the zeolite treatment.

Apparent efficiency of absorption (AEA\%) at $6 \mathrm{~h}$ after partus and statistical significance of differences between means for all four groups of calves are presented in Figure 2.

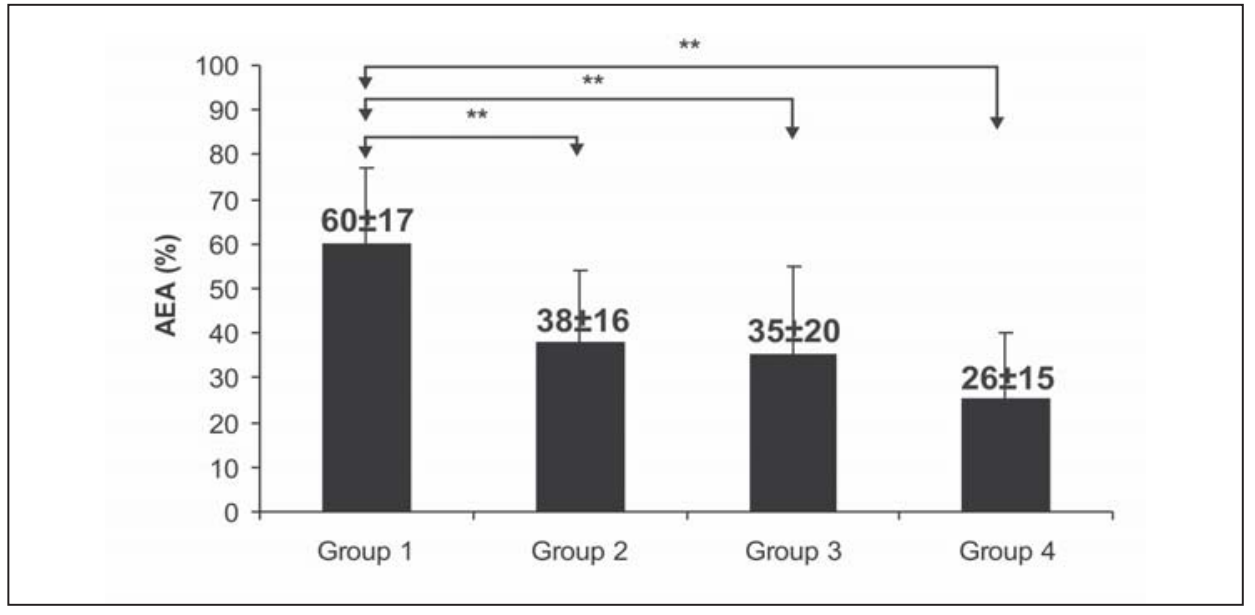

Figure 2. Apparent efficiency of absorption $(X \pm S D, \%)$ at 6 . hours after partus $(* \star-p<0.01)$

Apparent efficiency of absorption at $6 \mathrm{~h}$ after partus was significantly higher in $\mathrm{G} 1$ treated with zeolite and receiving $0.75 \mathrm{~L}$ of colostrum, compared to all other experimental groups. Value of $A E A \%$ in $\mathrm{G} 2$, receiving zeolite treatment and $1.5 \mathrm{~L}$ of colostrum was not significantly different compared to G3 $(38 \pm 16: 35 \pm 20, p=$ 0.601 ), but the statistical significance of difference between $A E A \%$ means for $G 2$ and $\mathrm{G} 4(38 \pm 16: 25 \pm 15)$ was $p=0.051$.

Success of passive immunity transfer is typically assessed by measuring calves blood serum IgG concentrations at 24 to 48 hours after partus. Blood serum IgG concentration in calves may be influenced by many factors, including the age at the first feeding (Rajala et al., 1995), sex of the calf and body weight (Roy, 1990), amount of IgG consumed (Besser et al., 1985), colostrum quality (Hough et al., 1990) and method of colostrum feeding (Brignole et al., 1980). Oral zeolite treatment induced an increase in calf blood serum IgG concentration in G1 and G2 (Table 3), at $6 \mathrm{~h}$ after partus. This effect was evident later on at $24 \mathrm{~h}$ and $48 \mathrm{~h}$ after partus. The treatment effect on the time scale was more evident in G1, receiving $0.75 \mathrm{~L}$ of colostrum than in $\mathrm{G} 2$, that received $1.5 \mathrm{~L}$ of colostrum. Besser 
Acta Veterinaria (Beograd), Vol. 58. No. 4, 345-355, 2008.

et al. (1985) suggested that the prevalence of failure of passive transfer in dairy herds could be minimized by artificially feeding calves large volumes ( 3 to $4 \mathrm{~L}$ ) of fresh or refrigerated colostrum within the first $24 \mathrm{~h}$. Intake of colostral IgG has a marked influence on blood IgG concentrations (Hopkins et al., 1997), with a positive linear relationship. When less than $2 \mathrm{~L}$ of first milking colostrum are fed the concentration of Ig in the colostrum may be insufficient to ensure the transfer of an adequate quantitiy of $\lg$ (Quigley et al., 1998). However, our results are similar to the results of Jaster (2005), who reported a significant increase in serum IgG $_{1}$ concentrations at $24 \mathrm{~h}$ in calves fed $2 \mathrm{~L}$ of colostrum with high $\mathrm{IgG}_{1}$ concentrations. Using reduced amounts of colostrum $(0.75 \mathrm{~L}$ in $\mathrm{G} 1$ and $\mathrm{G} 3$, and $1.5 \mathrm{~L}$ in $\mathrm{G} 2$ and G4), we have tried to minimize the effect of the colostrum amounts on serum Ig concentrations, which could mask an influence of zeolite treatment. Not surprisingly, the increase in the amount of ingested colostrum (from $0.75 \mathrm{~L}$ to $1.5 \mathrm{~L}$ ) induced an increase in serum IgG concentrations (Table 3), but interestingly, the effect of zeolite treatment was similar to the effect of increased amount of colostrum fed.

It has been recommended that Holstein calves should be fed $1.98 \mathrm{~L}$ of colostrum in the first few hours of life, followed by an additional $1.89 \mathrm{~L}$ within $12 \mathrm{~h}$ (Roy, 1980). The recommendation given by Besser et al., (1985) and Gay (1994) is $3.78 \mathrm{~L}$ of colostrum by oesophageal feeder immediately after birth, with the second feeding of $1.89 \mathrm{~L} 12 \mathrm{~h}$ later on. Bovine Alliance on Management and Nutrition (1995) concluded that $2.84 \mathrm{~L}$ of colostrum fed soon after birth is adequate. Furthermore, if the quality of colostrum can be determined, this group recommends feeding only $1.89 \mathrm{~L}$ at birth. All those recommendations are aimed to the target of at least $10 \mathrm{~g} / \mathrm{L}$ calf serum Ig concentration at $48 \mathrm{~h}$ of age. Our results show that feeding $0.75 \mathrm{~L}$ of high quality colostrum with oral zeolite treatment could produce calf blood serum IgG concentration well above the recommended value at $6 \mathrm{~h}$ of age. Furthermore, increasing the amount of colostral intake to $1.5 \mathrm{~L}$, combined with oral zeolite, could also increase serum IgG concentration above $15 \mathrm{~g} / \mathrm{L}$ at $6 \mathrm{~h}$ of age, which is probably more desirable as a management target to reduce calf morbidity and mortality (Davis et al., 1998).

Apparent efficiency of absorption helps to better understanding of the nature of $\lg G$ absorption. The AEA\% measures the efficiency with which $\lg$ are absorbed, not the total Ig absorption. Mean AEA\% from maternal colostrum typically averages 20 to $35 \%$ (Quigley et al., 1998), and may be influenced by the concentration of IgG in the colostrum (Stott et al., 1979c; Stott et al., 1983; Besser et al., 1985). Stott et al. (1983) reported a linear response, where calves fed $1 \mathrm{~L}$ of colostrum were more efficient in absorbing IgG than were calves fed the same mass of IgG in $2 \mathrm{~L}$. Besser et al. (1985) reported a significant negative correlation between AEA\% and mass of IgG fed to the calves. Stott et al. (1979c) suggested that the relationship between $A E A \%$ and IgG intake is curvilinear, and that an excessive amount of colostrum may cause inhibition of Ig absorption, particularly with increasing age. It seems that reduction in absorption efficiency leads to $2 \mathrm{~L}$ of colostrum as an optimum to be fed to the average large-breed calves at birth up to $16 \mathrm{~h}$ (Stott et al., 1979c). The most significant increase in mean AEA\% value at $6 \mathrm{~h}$ after partus in our experiment was obtained with oral zeolite treatment in calves 
receiving $0.75 \mathrm{~L}$ of high quality colostrum (60\%). This increase of mean $A E A \%$ value resulted in calf blood serum IgG concentration similar than IgG concentration in calves receiving $1.5 \mathrm{~L}$ of high quality colostrum. Doubling the amount of colostrum obviously reduced $A E A \%$ value in zeolite treated calves (from $60 \%$ in $\mathrm{G} 1$ to $38 \%$ in G2), the effect also being apparent in calves receiving only their mothers colostrum, but on a much smaller scale (from 35\% in G3 to 26\% in G4). Our results for AEA\% value in G2 and G4 are similar to the results reported by Qugley et al., (1998), but this is the first report we know about the possible modification of $A E A \%$ in newborn calves. It seems that oral clinoptilolite treatment could modify the process of IgG absorption in two ways: 1) increasing AEA\%, and 2) making it's dynamics similar to the situation in which calves were fed with more than $2 \mathrm{~L}$ of high quality colostrum. In his recent extensive rewiew Papaioannou et al., (2005) summarized proposed mechanisms involved in animals performance promoting properties of the dietary use of natural and synthetic zeolites as feed additives. Among those mechanisms two could have impact on the AEA\% value in newborn calves: 1) ammonia binding effect, which eliminates toxic effects of $\mathrm{NH} 4^{+}$produced by intestinal microbial activity, and 2) slowing the passage rate of digesta trough the intestine. Regarding the first mechanism of ammonia binding it could eliminate negative effects of microbial destruction of proteins which are abundant in colostrum, and could be further increased thanks to the lower rate of proteolytic enzyme activity in newborn calves intestine (Hardy, 1969; James et al., 1978). Reduction of ammonia toxic effects could also contribute to the increased survival rate and pinocytotic activity of early postnatal enterocyte population that has the unique ability to absorb intact macromolecules. The uptake of macromolecules by the intestinal epithelial cells could be non-specific and receptor mediated endocytosis. Selective immunoglobulin absorption in rats involves binding of the molecules to the $\mathrm{Fc}$ recetors of the microvillous membrane of the epithelial cells in the jejunal region, and non-specific absorption occurs in the ileal region of the small intestine (Weaver et al., 1989). It seems that IgG absorption in calves is meadiated mostly by non-specific mechanisms, since radiolabeld $\gamma$-globuline uptake is greatest in the caudal parts of the ileum (James et al., 1978). However, both mechanisms suggested by Papaioannou et al, (2005) could be responsible for the increase of $A E A \%$, but the exact explanation of zeolite effect on efficiency of IgG absorption in newborn calves still remains to be elucidated.

ACKNOWLEDGEMENTS:

The Ministry of Science and Technology, Republic of Serbia, Project Grant No. 143022 supported this research.

Address of correspondence:

Dr Dragan Gvozdić,

Department of pathophysiology,

Faculty of Veterinary Medicine,

University of Belgrade,

11000 Belgrade

Bul. oslobodjenja 18

Serbia

e-mail: gvozdic@vet.bg.ac.yu 


\section{REFERENCES}

1. Abel Francisco SF, Quigley JD, 1993, Serum immunoglobulin concentrations after feeding maternal colostrum or maternal colostrum plus colostral supplement to dairy calves, Am J Vet Res, 54, 1051-4.

2. Arthington JD, Cattell MB, Quigley III JD, McCoy GC, Hurley WL, 2000, Passive immunoglobulin transfer in newborn calves fed colostrum or spray-dried serum protein alone or as a supplement to colostrum of varying quality, J Dairy Sci, 83, 12, 834-8.

3. Besser TE, Garmedia AE, McGuire TC, Gay CC, 1985, Effect of colostral immunoglobulin G1 and immunoglobulin M concentrations on immunoglobulin absorption in calves, J Dairy Sci, 68, 2033-7.

4. Besser TE, Gay CC, 1994, The importance of colostrum to the health of the neonatal calf, Vet Clinics North Am, 10, 107-17.

5. Bovine Alliance on Management and Nutrition, 1995, A guide to colostrum and colostrum management for dairy calves, American Feed Industry Association, Arlington, VA.

6. Brignole TJ, Stott GH, 1980, Effect of suckling followed by bottle feeding colostrum on immunoglobulin absorption and calf survival, J Dairy Sci, 63, 451- 6.

7. Cebello G, Levieux D, 1980, Comparative absorption of colostral IgG1 and IgM in the newborn calf, Effects of thyroxine, cortisol and environmental factors, Ann Rec Vet, 11,1, 1-7.

8. Daković A, Matijašević S, Rottinghaus GE, Dondur V, Pietrass T, Clewett FM, 2007, Adsorption of zearalenone by organomodified natural zeolitic tuff, J Colloid Interface Sci, 311, 8-13.

9. Davis CL, Drackley JK, 1998, Colostrum. in The Development, Nutrition, and Management of the Young Calf, lowa State Univ Press, Ames, IA, 179-206.

10. Edwards SA, Broom DM, Collis SC, 1982, Factors affecting levels of passive immunity in dairy calves, Br Vet J, 138, 233-6.

11. Filteau V, Bouchard E, Fecteau G, Duti L, Dutremblau D, 2003, Health status and risk factors associated with failure of passive transfer of immunity in newborn beef calves in Quebec, Can Vet $J, 44,907-13$.

12. Foley JA, Otterby $D E, 1978$, Availability, storage, treatment, composition, and feeding value of surplus colostrum: A review, J Dairy Sci, 61,1033-60.

13. Fratrić Natalija, Stojić V, Janković D, Šamanc $H$, Gvozdić $D, 2005$, The effect of a clinoptilolite based mineral adsorber on concentrations of immunoglobulins $\mathrm{G}$ in the serum newborn calves fed different amounts of colostrum. Acta Veterinaria, Beograd, 55,1, 11-21.

14. Garry FB, Adams R, Cattell MB, Dinsmore RP, 1996, Comparison of passive immunoglobulin transfer to dairy calves fed colostrum or commercially available colostral-supplement products, JAVMA, 208,107-10.

15. Gay C, 1994, Colostrum research says feed 4 quarts for healthier calves, Heard's Dairyman, 139, 256.

16. Hardy RN, 1969, Proteolytic activity during absorption of [131l]g-globulin in the newborn calf, $J$ Physiol, 205, 453-70.

17. Hopkins BA, Quigley III JD, 1997, Effects of method of colostrum feeding and colostral supplementation on serum IgG concentrations in neonatal calves, J Dairy Sci, 80, 979-83.

18. Hough RL, McCarthy FD, Kent HD, Eversole DE, Wahlberg ML, 1990, Influence of nutritional restriction during late gestation on production measures and passive immunity in beef cattle, $J$ Anim Sci, 68, 2622-7.

19. Husband AJ, Brandon MR, Lascelles AK, 1973, The effect of corticosteroid on absorption and endogenous production of immunoglobulins in calves, Aust J Exp Biol Med Sci, 51,5, 707-10.

20. James RE, Polan CE, 1978, Effect of orally administered duodenal fluid on serum proteins in neonatal calves, J Dairy Sci, 61, 1444-9.

21. Jaster $H E, 2005$, Evaluation of quality, quantity, and timing of colostrum feeding on immunoglobulin $\mathrm{G}_{1}$ absorption in Jersey calves, $J$ Dairy Sci, 88, 296-302.

22. Kruse $P E, 1983$, The importance of colostral immunoglobulins and their absorption from the intestine of the newborn animals, Ann Rech Vet, 14,4, 349-53. 
23. Lee RB, Besser TE, Gay CC, Mcguire TC, 1983, The influence of method of feeding on IgG concentrations acquired by calves, Proc $4^{\text {th }}$ Int Symp Neonatal Diarrhea, VIDO, Saskatoon, SK, Canada, 373-7.

24. Mee JF, O'Farrell KJ, Reitsma P, Mehra R, 1996, Effect of a whey protein concentrate used as a colostrum substitute or supplement on calf immunity, weight gain, and health, J Dairy Sci, 79, 886-94.

25. Mihajlović-Radosavljević A, Daković A, Lemić J, Matijašević S, Tomašević-Čanović M, 2003, Physical chemical properties and acid stability of zeolitic tuff. In Kuzev L, Nishkov I, Boteva A, Mochev D (Eds.), Mineral Processing in the 21st Century, Proceedings of the X Balkan Mineral Processing Congress, Varna, Bulgaria, 15-20 July 2003, 897-902

26. Morin DE, McCoy GC, Hurley WL, 1997, Effects of quality, quantity, and timing of colostrumfeeding and addition of a dried colostrumsupplement on immunoglobulin $\mathrm{G}_{1}$ absorption in Holstein bull calves, J Dairy Sci, 80,747-53.

27. Mumpton FA, 1998, Development of uses for natural zeolites: a critical commentary. In: Kallo D, and Sherry HS (Eds), Occurence, Properties and Utilization of Natural Zeolites, Akademia Kiado, Budapest, 333.

28. Papaioannou D, Katsoulos PD, Panousis N, Karatzias $H, 2005$, The role of natural and synthetic zeolites as feed additives on the prevention and/or the treatment of certain farm animal diseases: A review. Micropor Mesopor Mater, 84, 161-70.

29. Pedersen RE, Paulrud CO, Tucker WB, 2000, Influence of bovine antiserum (Bo-Bac 2X) injection on colostral immunoglobulin G absorption in neonatal dairy calves, J Dairy Sci, 83, 2829-33.

30. Quigley III JD, Drewry JJ, 1998, Nutrient and immunity transfer from cow to calf pre- and postcalving. J Dairy Sci, 81, 2779-90.

31. Quigley III JD, Martin KR, Dowlen HH, Lamar KC, 1995, Addition of soybean trypsin inhibitor to bovine colostrum: effects on serum immunoglobulin concentrations in Jersey calves, $J$ Dairy Sci, 78, 886-92.

32. Quigley III JD, Welborn G, 1996, Influence of injectable immunoglobulin on serum immunoglobulin concentrations in dairy calves, J Dairy Sci, 79, 2032-7.

33. Rajala P, Castre ' $n H$, 1995, Serum immunoglobulin concentrations and health of dairy calves in two management systems from birth to 12 weeks of age, J Dairy Sci, 78, 2737-44.

34. Rea DE, Tyler JW, Hanckok TE, Besser TE, Wilson L, Krytenberg S, Sanders SG, 1996, Prediction of calf mortality by use of tests for passive transfer of colostral immunoglobulin, J Am Vet Med Ass, 208, 2047-9.

35. Roy JHB, 1980, Factors affecting susceptibility of calves to disease, J Dairy Sci, 63, 650-64.

36. Roy JHB, 1990, The Calf. Vol. I. Management of Health. Butterworths, Boston, MA.

37. Stojić V, Gagrčin M, Kirovski Danijela Fratrić Natalija, 1998. The effect of clinoptilolitebased mineral adsorber immunoglobulin G absorption in newborn piglets, Acta Veterinaria, Beograd, 48, 1, 19-26.

38. Stojić V, Šamanc H, Fratrić Natalija, 1995, The effect of a clinoptilolite based mineral adsorber on colostral immunoglobulin G adsorption in newborn calves, Acta Veterinaria, Beograd, 45, 2-3, 67-74.

39. Stott GH, Fellah A, 1983, Colostral immunoglobulin absorption linearly related to concentration for calves, J Dairy Sci, 66,6, 1319-28.

40. Stott GH, Marx DB, Menefee BE, Nightengale GT, 1979a, Colostral immunoglobulin transfer in calves II. The rate of absorption, J Dairy Sci, 62, 1766-73.

41. Stott GH, Marx DB, Menefee BE, Nightengale GT, 1979b, Colostral immunoglobulin transfer in calves III. Amount of absorption, J Dairy Sci, 62, 1902-7.

42. Stott GH, Marx DB, Menefee BE, Nightengale GT, 1979c, Colostral immunoglobulin transfer in calves IV. Effect of suckling, J Dairy Sci, 62, 1908-13.

43. Vukotić M, Movsesijan M, 1976, A relationship between the concentrations of immunoglobilin $\mathrm{G}$ in precolostral and postcolostral sera of calves, Acta Veterinaria, 26, 4, 181-6.

44. Vukotić M, Stojić V, 1979, An evaluation of frequency distribution of serum IgG concentrations in newborn precolostral calves, Period Biolog, 31, 285-6. 
Acta Veterinaria (Beograd), Vol. 58. No. 4, 345-355, 2008.

45. Ward RL, McKague HL, 1994, Clinoptilolite and heulandite structural differences as revealed by multinuclear nuclear magnetic resonance spectroscopy, J Phys Chem, 98, 1232-7.

46. Weaver LT, Walker WA, 1989, Uptake of macromolecules in the neonate, In Human Gastroenerology Development (E. Lebenthal ed), Raven Press, New York, 731-48.

47. Wittum TE, Perino LJ, 1995, Passive immune status at postpartum hour 24 and long-term health and performance of calves, Am J Vet Res, 56, 9, 1149-54.

\title{
RELATIVNA EFIKASNOST RESORPCIJE IMUNOGLOBULINA KOD NOVOROĐENE TELADI ORALNO TRETIRANE ZEOLITOM
}

\author{
GVOZDIĆ D, STOJIĆ V, ŠAMANC H, FRATRIĆ NATALIJA i DAKOVIĆ ALEKSANDRA
}

\section{SADRŽAJ}

Šezdeset novorođenih teladi Holštajn rase, koja su neposredno nakon rođenja odvojena od majki i stavljena u individualne bokseve, su metodom slučajnog izbora podeljene u 4 ogledne grupe (15 teladi po grupi). Sva telad su za vreme prvih 48 sati života hranjena dva puta dnevno (u intervalu od 12 sati) kolostrumom majki, počevši od drugog sata nakon partusa prema sledećem eksperimentalnom modelu: i) grupa 1 (G1) dobijala je 0.75 L kolostruma (C) po obroku, sa dodatkom $20 \mathrm{~mL}$ suspenzije $25 \%$ zeolita (klinoptilolita) u destilovanoj vodi; ii) grupa 2 (G2) dobijala je $1.5 \mathrm{~L} \mathrm{C}$ po obroku, sa dodatkom $20 \mathrm{~mL}$ suspenzije $25 \%$ zeolita (klinoptilolita) u destilovanoj vodi; iii) grupa 3 (G3) dobijala je $0.75 \mathrm{~L} \mathrm{C} \mathrm{po}$ obroku; iv) grupa 4 (G4) dobijala je $1.5 \mathrm{~L} \mathrm{C}$ po obroku. Koncentracija imunoglobulina $G$ (IgG) određivana je komercijalnim radijalnim imunodifuzionim testom (sRID, INEP, Zemin) u krvnom serumu dobijenom iz uzoraka krvi uzetih punkcijom v. jugularis pre uzimanja kolosruma (0. sat), 6-og, 24-og i 48-og sata nakon rođenja, dok je relativna efikasnost apsorpcije imunoglobulina (AEA\%) određena 6 -og sata po rođenju. Koncentracija IgG u krvnom serumu kod teladi iz grupe G1 u odnosu na G2 bila je viša 6-og, 24-og i 48-og sata, dok je statistička značajnost razlika srednjih vrednosti ustanovljena 6 -og sata po rođenju $(15 \pm 4: 10 \pm 5 \mathrm{~g} / \mathrm{L}$, $\mathrm{p}<0.05)$. Isti odnos srednjih vrednosti koncentracije IgG u krvnom serumu novorođenih teladi je zabeležen između grupe G2 i G4, gde su statistički značajno više srednje vrednosti utvrđene kod grupe G2 u odnosu na G4 u periodu 6, 24. i 48. sati po rođenju ( $p<0.01$ za sve navedene vremenske periode). Relativna efikasnost apsorpcije 6-og sata po rođenju je bila statistički vrlo značajno viša $(p<0.01)$ kod grupe $G 1$ u odnosu na ostale ogledne grupe teladi. 